of a plant's full genetic potential with high stem to leaf ratio, low protein content or accumulation of repellants in the mature leaf, also acts against grazing animals, in particular large coarse feeders which are less able to select parts of plants. In these species at least, the absence of the predatory control suggested by Hairston, Smith \& Slobodkin (1960) appears to have been filled by a nutritional control of their populations.

The author wishes to thank the committee and staff of the Nuffield Unit of Tropical Animal Ecology and the Trustees and staff of the Uganda National Parks for their help and co-operation.

\title{
REFERENCES
}

Bate-Smith, E. C. \& Swain, T. (1967), Nature, Lond. 2r3, 1033.

Bere, R. M. (1959). Oryx 5, II6.

Bourlière, F. (1965). Zoologica Africana r, 199.

Buechner, H. K. (1950). Am. Midl. Nat. 43, 275.

Darling, F. F. (r960). Wildlife in an African Territory, ist ed. London: Oxford University Press.

Dirschl, H. J. (1962). F. Wildl. Mgmt 26, 327.

Eddy, T. A. (1961). F. Wildl. Mgmt 25, 248.

Elton, C. (1927). Animal Ecology, ist ed. London: Sidgwick \& Jackson Ltd.

Field, C. R. (1967). Zoologica Africana 3. (In the Press.)

Field, C. R. (1968a). Symp. zool. Soc. Lond. no, 21.

Field, C. R. (I968b). Food habits of some wild ungulates in Uganda. PhD Thesis, University of Cambridge.

Frädrich, H. (1965). Z. Tierpsychol. 22, 328.

Gause, G. F. (1934). The Struggle for Existence. Baltimore: Williams \& Wilkins Co.

Hairston, N. G., Smith, F. E. \& Slobodkin, L. B. (1960). Am. Nat. 94, 42 I.

Harper, J. A. (r962). F. Wildl. Mgmt 26, 97.

Lamprey, H. F. (1963). E. Afr. Wildl. \%. 1, 63.

Laws, R. M. (1967). In East African Wildlife-Land use Symposium. (In the Press.)

Laws, R. M. \& Field, C. R. (1964). Report and Accounts of the Uganda National Parks, p. 28. Kampala: Uganda Argus Ltd.

Luck, C. P. \& Wright, P. G. (1964). Q. $\mathscr{l} l$ exp. Physiol. 49, 1.

Napier Bax, P. \& Sheldrick, D. L. W. (1963). E. Afr. Wildl. F. I, 4 o.

Petridges, G. A. \& Swank, W. G. (1963). Zoologica Africana 1, 209.

Stewart, D. R. M. (1965). Bot. $7 b .84,63$.

Stewart, D. R. M. (1966). A technique for studying the food preferences of grazing herbivores. $\mathrm{PhD}$ Thesis, University of East Africa.

Stewart, D. R. M. (1967). F. appl. Ecol. 4,83.

Talbot, L. M. \& Talbot, M. H. (1963). Trans. N. Am. Wildl. Conf. 28, 465.

Warner, A. C. I. (1962). F. gen. Microbiol. 28, 1 19.

Watson, R. M. (1967). Population ecology of the wildebeeste in the Serengeti. PhD Thesis, University of Cambridge.

White, R. W. (1962). F. Wildl. Mgmt. 25, 404.

\section{Application of findings of research in animal nutrition to man}

\section{By W. F. J. Cuthbertson, Glaxo Research Ltd, Greenford, Middlesex}

Studies on animal nutrition have been and will continue to be of great importance. Such investigations can be used to check the dietary origin of certain human diseases, 
whether arising from deficiencies of nutrients, a plethora of certain components or from contaminations. Animal tests are essential in biological assays and for the identification of the biochemical, physiological and pharmacological roles of food components while, last but not least, animal nutrition studies have been successfully applied greatly to increase the economic production of meat and animal foods for human consumption.

By contrast, the application of research in animal nutrition to man has often been slow, irregular or incomplete. It may appear strange that deficiency diseases are prevalent in the world when the foods and specific substances required for their cure are well known, as are the methods for producing them by agricultural or manufacturing processes. Plethoric diseases also are common even though the cause may be known and the remedy easily to hand. Proper application of presently available knowledge could eliminate much ill-health suffered by the overfed as well as that endured by the underfed. This continued prevalence of nutritional disease in both developed and developing societies is all the more striking because medical findings have been quickly applied effectively to control many microbial diseases.

Dietary illnesses are more difficult to prevent; they are not transmissible, thus they cannot be checked by public health measures such as purification of water or proper disposal of sewage, nor can they often be controlled by a single course of a therapeutic substance. The nutrients which cure deficiencies must be distributed to and consumed by the people to be protected and this distribution must be assured at frequent intervals for the whole of the life span.

The nutrition of intensively reared animals, babies, prisoners, boarding-school boys, and sailors, is much more easily controlled than that of extensively reared animals or apparently free people. The latter though they appear to be free and well able to look after themselves may, if in a deprived group, find themselves prevented, by economic stress, social customs or sheer ignorance from eating those foods needed for full health, or if in a better-off group in either a developed or a developing country they may fill their stomachs regardless of all except the pleasurable sensations of eating and so risk plethoric diseases which may require both knowledge and self denial to avoid.

\section{Vitamin and trace nutrient deficiencies}

In spite of many difficulties, there has been very great progress in the control of vitamin and mineral deficiency diseases in developed areas. This has been done mainly by taking advantage of the highly organized food processing and distribution systems and consumption patterns in these countries. For instance, the standard practice among the undeprived of feeding their infants on processed foods prepared at centralized factories, has made it easy to ensure the addition of vitamin $D$ to these foods and so eliminate rickets. Similarly, the large-scale manufacture of bread flour, salt and fatty spreads has provided the opportunity to fortify these items with certain nutrients (iron, calcium, certain water-soluble vitamins, iodine, vitamins $A$ and $D)$ and so introduce these essentials into the diet of almost the whole popula- 
tion in a number of developed countries. Procedures of this type have proved possible for the following reasons:

(I) The cost of the nutrients needed is small and the extra equipment to ensure their distribution in the food is not costly to acquire or expensive to run;

(2) the additives do not adversely affect food quality (taste, etc.) as judged by the ultimate consumer;

(3) the additives do not adversely modify the technological characteristics of the materials to which they have been added;

(4) the foods to which the additions are made are produced in a small number of factories so that analytical and legal control of the rate of addition is not difficult to carry out or to enforce.

In the less highly organized developing countries the situation is rather different. Almost always far less processed food is bought. Usually food processing is done with simple equipment without scientific control in small establishments serving limited areas-a town, a village or perhaps only the home-and is carried out on locally grown produce. Furthermore, appropriate methods of food enrichment may require development. The problems of rice fortification for instance, because of the ways in which it is used, are quite different from those appropriate for bread flour. All the same, nutrient supplementation of staples and some other foods could have a significant effect on the health of certain groups, notably urban and semiurban people dependent on processed staples prepared in a limited number of factories.

\section{Major shortages}

In many areas of the world populations suffer from shortages of the major food components-protein, fat and carbohydrates. These deficiencies have been described as protein malnutrition, protein-calorie malnutrition or, less politely, as hunger or starvation. Here the missing nutrients are neither cheap nor small in bulk, nor is it easy to incorporate them into food which itself is in short supply! The problem can only be overcome by increasing the availability of food for the needy. This may be done in several ways. Outright gifts of food, though vital in emergency, have no permanent value and may in the long run do harm because the availability of donated or imported food may depress demand for local food and thus discourage production by local farmers. 'The population should be encouraged to provide food for itself or to make available materials and services to be exchanged for food. In a rural subsistence economy food can only be provided by the people themselves for themselves. In an urban economy the townsfolk must provide the food producers, farmers, hunters or fishermen with goods and services as incentives to provide the extra food they need.

With present-day knowledge it is possible greatly to increase food production almost anywhere in the world, often not by 10 or $20 \%$ but by factors of five- or even ten-fold. If then this is possible why has it not been done? There is no general answer, the developing countries and deprived populations throughout the world are as they are for a wide variety of reasons, and until these are understood the 
most effective remedies cannot be proposed for any particular instance. The cause may be ignorance on the part of the farmer, ignorance of good cultivation methods, disregard of fertilizers, insecticides and herbicides or failure to use more productive tools, plants or animals. Much more often the increased yield will not pay for the increased cost of the extra capital equipment, materials and labour almost invariably essential for more productive methods. Difficulties may arise for a variety of reasons. Some may concern land tenure and use, others may be caused by shortage of capital and high interest rates, and still others may relate to poor communications and consequent excessive transport charges. Frequently there may be lack of incentive; if the townsfolk will not or cannot pay for food, by providing the goods and services the farmer wants, then he will not work harder and risk more to produce more. Conversely if conditions can be made appropriate it is surprising with what speed conservative farmers will adopt new methods-if they are more profitable-and so increase food production.

\section{Foods for deprived groups}

Within almost all countries, developed as well as undeveloped, there are classes or groups of people suffering from malnutrition. Here again quite different measures may be needed depending on the deficiencies, and on the victims, whether they be infants or old age pensioners, landless farm labourers or underprivileged immigrants or people with odd food habits. In some instances all that is needed may be proper advice for loving but ignorant relations, in others provision of adequate work or opportunities to earn cash. Sometimes government assistance schemes may be essential while in still others changing conditions may require new foods. An example of this latter type is the need for suitable infant foods. In many developing countries the achievement of a cash economy and the new socio-economic pressures of developing urbanization make it increasingly difficult for mothers to breast-feed children. Babies are thus weaned at a few months rather than at $18-24$ months of age. They are then reared predominantly on starchy gruels deficient in protein and often so bulky that the infant is unable physically to imbibe even its daily calorie requirement. Thus the newly-weaned baby is given a low-protein, low-caloric diet. Even when, as a toddler, he is old enough to take his place at the family meal, the child usually still suffers because he has only the smallest portions of what little proteinaceous food may be available. Although the parents cherish their children dearly, they often do not know what the infant needs or how to prepare his food. The position is exacerbated in that under such circumstances fresh milk is usually not available and dried milk and baby foods are frequently much too expensive to be used regularly in sufficient amount. Under these circumstances education in good nutrition can be of help but it is difficult for overworked and underprivileged mothers living in poor dwellings with inadequate facilities to find time to acquire the knowledge, develop the skills, and do the work of preparing and feeding the foods needed by very young children. It is for these reasons that the distribution of skim-milk powder has been of such enormous benefit to thousands of children all over the world. Unfortunately, the cost of skim-milk powder has risen greatly-it is more 
profitable to sell the powder to rear calves for veal than to distribute it at low cost to needy children. The development of a cheap food which could be used for weaning children or perhaps even instead of dried-milk foods for babies, could be of inestimable benefit to children in developing countries especially if it could be made from indigeneous materials because most developing countries are deficient in foreign exchange as well as in milk!

Progress in the pig and poultry industries since the war has demonstrated, once nutritional needs for a single-stomached animal have been defined, how easy it is to manufacture cheap foods of very high nutritional value, so much so that on such foods animals can grow and prosper (until they reach the slaughterhouse) with speeds and efficiencies which were undreamt of 30 years ago when farm animals were fed on more natural rations. Similarly it has not proved difficult to design a range of infant foods of high nutritional value capable of promoting excellent growth and well-being in children. These can be made from a variety of raw materials in plentiful supply in a number of developing countries. The protein moiety of such foods can be contributed by a suitable processed oilseed residue (soya bean, groundnut, or cottonseed for instance). Cereal flours can provide the calories, minerals and vitamins can be added as needed, and amino acids (methionine or lysine) may be incorporated to improve protein quality. Such foods, though they would appear to be cheap to produce, may not in fact be so. The raw materials may require special manufacture and so be expensive, if they are to conform with specifications of quality often drawn up by people without practical experience in the countries concerned. Manufacturing, packaging, distribution and advertising costs are almost invariably greater than in the more developed countries and all these factors must be reflected in the price the ultimate consumer must pay. In spite of these difficulties many such foods have been proposed and manufactured but almost all have failed, not because they were nutritionally ineffective but because sufficient people could not be persuaded to buy them and feed them to their children. Many and varied excuses have been made for these failures but at least one common feature can be seen. Sufficient attention has rarely been paid to the palatability and attractiveness of the food and its suitability for its purpose in the socio-economic circumstances of the people who are expected to buy and eat it. Until these requirements are met, as well as the nutritional needs, there is scant hope that these new foods will be eaten by infants in developing areas. Human beings are free not to eat and not to give their children what they dislike. No matter how wholesome and nutritionally valuable a food may be, it will not be eaten unless it gains approval. People pay or work for food and eat it because they enjoy doing so-if it is unpleasant it will not be consumed except under extreme conditions. In England many eat a nutritious dieteggs and sausage, tea, bread and butter, marmalade, tea and bun, meat and two vegetables, pickles, fruit or cheese, coffee, and so on throughout the day. If this were passed through an homogenizer and freeze-dried, the powder would be equally nutritious, but does even the most devoted nutritionist believe that anyone would willingly eat it! No mother will willingly feed her children on food which she does not think suitable, nor will it be pressed on babies and infants if they do not like it. 
In some societies a food will not be used for babies unless the grandmother approves it, father is able and willing to provide the cash for it, mother wants to feed it and baby is willing to eat. In these circumstances a food which fails to meet any of these four criteria will not be used, while if it fails to meet either of the last two it is difficult to imagine it being used under any circumstances. It cannot be emphasized too strongly that nutritional value is of little significance in determining whether or not a food will be eaten. In England $90 \%$ of mothers believe brown bread to be more nutritious than white, yet $90 \%$ of them buy white bread. If so little attention is paid to nutrition teaching in the UK how much can be expected in the developing countries?

\section{The food crisis}

At the present time it is believed that the world is rapidly approaching a food crisis and that a world shortage of protein is developing. Much has been said and written about the potential value of oilseed protein residues for feeding man, though most applications have been for feeding farm stock. Animals are more easily forced to eat, and it is financially more rewarding to feed them, than underprivileged human beings. Oilseed technology in the Western world has been developed primarily to yield oil and secondarily to yield an oilseed residue suitable for animal feeding. Until recently little work has been done on the preparation of the protein-rich residues in a form suitable for human consumption. These residues are cheap because, though they are nutritious, people do not like eating them. Because they are not attractive as foods it is scarcely surprising that most foods so far made from them are in their turn without much gastronomic merit.

Animal tests have shown that many unicellular organisms which could be produced in vast quantities, yeasts grown on a number of agricultural products and industrial wastes, algae cultured in various ways, yeasts and bacteria grown on certain hydrocarbons, appear to have special potential as sources of protein. Much work remains to be done on the value of those possible new food materials, their toxicology and technology, before they may be applied directly or indirectly for human feeding. No attempt appears to have been made to find easily cultured organisms which might taste attractive and so be readily accepted as foods though the knowledge that many fungi and algae are highly prized foods encourages the belief that desirable food organisms could be identified and cultured.

A great deal of work is being done to develop methods of manufacturing, on a large scale, protein suitable for human consumption. Source materials are oilseed residues, species of fish which are easy to catch but not normally eaten, microorganisms such as algae, yeasts or bacteria and green leaves. Much has been made of the possibility that protein made from these waste or cheap sources will be suitable for feeding the deprived and underprivileged millions. Little has been said of how these people will be induced to eat these new products or how they may pay for them. These new proteins, even if sufficiently nutritious and safe for human consumption, will only be used if they can also be made sufficiently attractive for people to eat them and cheap enough for people to buy them. Proteins are odourless, 
colourless and tasteless substances which are also useless until they are eaten - and by themselves they are just not attractive--most of us have tasted egg albumen and casein but which of us have eaten even $20 \mathrm{~g}$ and then asked for a second helping of these wholesome and nutritious products. The purified proteins now availablecasein, egg albumen, wheat gluten, soya protein and groundnut protein isolaestare valued not for their nutritional quality but for their functional characteristics which are employed favourably to modify the physical nature of processed foods, such as sausages, cakes, meat dishes or bread. So the natural animal and vegetable protein sources are prized, not so much because of their nutritional virtues but because of textural qualities provided by the protein and because of the many and varied flavouring substances naturally associated with many proteins in nature. For a variety of reasons it is likely that none of the organisms (algae, yeasts or bacteria) at present proposed as protein sources will be found suitable for direct human consumption though they may be used indirectly, in animal food, to provide meat, milk and eggs. Alternatively, protein may be isolated from these organisms and then incorporated in human food. This latter proposal is attractive because this would avoid the heavy losses normally encountered in conversion of vegetable into animal protein but must await development of methods of separation and utilization. At present separation and raw material costs are such that isolated vegetable protein is more expensive than casein and its use thereby restricted.

\section{The future}

The future prospect for use of protein isolates may however be excellent. As knowledge of the flavouring agents, and the complex structural and physico-chemical features responsible for the attractive nature of foods becomes better understood so it may become possible to make 'synthetic' foods. Protein preparations appear to have great value for this purpose because they can be used to provide attractive structures giving desirable texture and 'chewing quality' to a solid food. In fact 'meat' and 'chicken' products based on vegetable protein are now being made. Ultimately these new foods will almost certainly be designed to be more attractive and to be preferred for many purposes to the natural meats and protein foods just as in other fields properly designed synthetic plastics are preferred to natural products because they are more effective. For similar progress with 'synthetic' flesh foods the effort will need to be comparable with that already made in polymer technology but with serious extra problems. Acceptability must be created even though the factors controlling this property cannot yet be easily measured or identified. At the same time any products must satisfy tests for the absence of toxic hazards in use, and it is to be hoped that provision will be made to ensure nutritional adequacy because it is quite possible that the characteristics for acceptability and desirability may be obtained by the use of proteins of little nutrient value or, indeed, perhaps by non-protein substances such as certain carbohydrates or modified starches.

Nutrient content may have scant effect on the choice of foods. Little may at present be known of the substances and qualities which make food attractive, but the 
food technologist has shown that it is possible to make truly delicious foods of little nutritional value while the nutritionist has designed many foods which proved unacceptable in spite of manifold nutritional virtues! The heart of the problem may prove to be that people like to eat and savour many things that are not nutrients but do not wish to spend time and effort in procuring and consuming things which though necessary may not be attractive.

In conclusion, I believe that a much deeper study of human factors (social, economic and physiological, for instance) affecting consumption of food by man is essential if the results of animal nutrition investigations are to be more extensively applied to improve human nutrition. The problem may prove to be a very difficult one and will certainly require work in a large number of different fields. 